\title{
Study on Structure Optimization of Public Finance Expenditure in Shaanxi Province-Based on the Background of Supply-Side Reform
}

\author{
Le Xu
}

Master Student of the Department of Economics and Management of Xidian University, China

\begin{abstract}
The structure of fiscal expenditure refers to the proportion of various types of financial expenditures in total expenditures. By analyzing the status quo of the fiscal expenditure structure in Shaanxi Province, this paper sorts out the problems existing in the fiscal expenditure structure in Shaanxi Province and puts forward some policy suggestions on how to optimize the expenditure structure in Shaanxi Province under the supply-side reform.
\end{abstract}

Keywords: structure of fiscal expenditure; supply-side reform; optimization

\section{Introduction}

Finance is the foundation and important pillar of state governance. It is the main guarantee for the optimal allocation of resources, the fair distribution of income, the steady economic growth and the harmonious social development. In 2015, general public budget expenditure in Shaanxi Province reached 205.995 billion yuan, an increase of 16.955 billion or $8.97 \%$ over the same period of previous year, 5.7 times that of 2006. The structure of public finance expenditure in Shaanxi Province has become increasingly prominent. Therefore, under the background of deepening fiscal and taxation system reform, how to optimize the structure of fiscal expenditure in Shaanxi Province, promote regional supply-side structural reforms and promote the smooth transition of economic development motivation, is the key to fully realizing a well-to-do society in the "13th Five-Year Plan" period The important topic.

Supply-side structural reform is a major strategic innovation initiative to take the initiative to adapt to the new economic development environment and take the initiative in leading the transformation of the mode of economic development under the new economic normal. In particular, we should change the concept of development and implement the five major development concepts of "innovation, coordination, greenness, openness and sharing." Therefore, under the background of supply-side reform, the optimization of local fiscal expenditure structure must meet the goal of supply-side reform.

\section{Analysis of the Financial Expenditure Structure in Shaanxi Province}

In 2015, Shaanxi's GDP was 1.8021 trillion yuan, an increase of $1.9 \%$ over the previous year. According to the resident population, the per capita GDP of 47,626 yuan, an increase of $1.5 \%$. The annual fiscal revenue of 205.995 billion yuan, an increase of $8.97 \%$ over the previous year, financial expenditure reached 437.606 billion yuan, an increase of $10.4 \%$ over the previous year.

Form one: 2006-2005 Analysis Table of Financial Expenditure in Shaanxi Province

Unit: billion yuan

\begin{tabular}{|c|c|c|c|c|c|}
\hline \multirow{2}{*}{ Years } & GDP & Revenue & Expenditure & $\begin{array}{c}\text { Financial } \\
\text { self-sufficiency rate }\end{array}$ & $\begin{array}{r}\text { Fiscal expenditure } \\
\text { growth elasticity }\end{array}$ \\
\cline { 2 - 4 } & Amount & Amount & Amount & 0.44 & \\
\hline 2006 & 4743.61 & 362.48 & 824.18 & 0.45 & 1.30 \\
\hline 2007 & 5757.29 & 475.24 & 1053.97 & 0.41 & 1.53 \\
\hline 2008 & 7314.58 & 591.48 & 1428.52 & 0.40 & 3.41 \\
\hline 2009 & 8169.80 & 735.27 & 1841.64 & 0.43 & 1.81 \\
\hline 2011 & 10123.48 & 958.21 & 2218.83 & 0.51 & 2.17 \\
\hline 2012 & 12512.30 & 1500.18 & 2930.81 & 0.48 & 3.10 \\
\hline 2013 & 14453.68 & 1600.69 & 3323.80 & 0.48 & 3.94 \\
\hline 2014 & 176205.45 & 1748.33 & 3665.07 & 0.48 & 5.21 \\
\hline 2015 & 18021.86 & 2059.95 & 4376.06 & 0.47 & 25.09 \\
\hline
\end{tabular}

First of all, in terms of absolute size, the total amount of public expenditures in Shaanxi Province has rapidly increased. From 2006 to 2015, the gross domestic product increased from 474.361 billion yuan to 1.82186 billion yuan with a net increase of 13.27825 billion yuan, an increase of 3.8 times with an average annual growth rate of $16.3 \%$. Secondly, judging from the relative size, Shaanxi's fiscal revenue and expenditure accounted for a steady increase in

\section{Volume 6 Issue 12, December 2017}




\section{International Journal of Science and Research (IJSR) \\ ISSN (Online): 2319-7064}

Index Copernicus Value (2016): 79.57 | Impact Factor (2015): 6.391

the proportion of its GDP. Shaanxi Province, the proportion of fiscal expenditure and regional GDP is higher than the proportion of fiscal revenue, while accounting for the gradual increase in the proportion of poor. Just confirmed the famous "Wagner's Law", with the per capita income increased, the proportion of fiscal expenditure in GDP also increased accordingly.

\section{Suggestions on Optimization of Fiscal Expenditure Structure in Shaanxi Province under the Background of Supply - side Reform}

The prerequisite for promoting economic restructuring and upgrading is that the supply-side structural reform should focus on transforming the mode of economic growth and optimize the concept of "innovation, coordination, openness and sharing" so as to accelerate the construction of modern finance.

\section{1) Establish Modern Financial System with Innovative Idea}

In the context of supply-side reform, we will give priority to the protection of funds in key areas and key links and at the same time, practice all aspects of economy, thriftiness and frugality. Strict control of administrative expenses, "three public" funds, conference fees, training costs, travel expenses, office equipment purchase costs and other general expenses negative growth budget. We will improve the state-owned assets management system of administrative institutions and further promote the combination of asset management and budget management. Through a series of reforms in the financial system, a modern financial system has been established, the structure of fiscal expenditure has been optimized and the financial capital efficiency has been enhanced.

2) To coordinate the concept of employment and social security policies

To ensure the basic and the bottom line as the goal, to rationally determine the level of social security projects, do what one can do to coordinate the handling of fund income and expenditure, financial subsidies and individual contributions, insist on actuarial balance, strengthen the incentive and restraint, improve the overall mechanism, Establish a more fair and more sustainable social security system.

\section{3) Promoting the Reform of Medical and Health System with Open Concept}

Vigorously support the development of medical and health undertakings, promote the establishment of a reasonable, stable and sustainable funding mechanism and gradually raise the overall funding standards and the proportion of individual contributions. Support the construction of major public health projects, pay attention to the cultivation of health personnel and improve the level of medical and health hardware and software. Increase food and drug safety regulatory investment, research and establish a long-term mechanism to ensure that regulatory funds.
4) The concept of sharing into education investment Adhere to the principle of an all-round education development, increase investment in pre-school education, focus on public-private partnerships and multi-channel expansion of preschool education resources. Improve the financial support for higher education, highlighting the quality of teaching and innovation, improve the per student appropriation system in vocational colleges, and explore the establishment of a financial input mechanism that fits with the requirements of running a school and training Vocational institutions to speed up the docking market, to achieve the funding system in all stages of education coverage.

\section{References}

[1] Wang Liyan. China's Financial Expenditure Structure Analysis and Optimization Management Based on Sustainable Economic Growth [M]. Shanghai; Lixin Accounting Press, 2016.

[2] Sun Chunlei. China's livelihood finance research [D]. Beijing; Ministry of Finance Institute of Finance, 2015. 